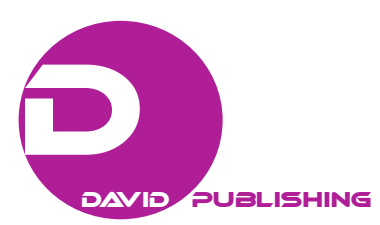

\title{
Evolution of Disabled Persons’ Telework Management in Business
}

\author{
Karolina Karbownik \\ University of Technology, Czestochowa, Poland
}

\begin{abstract}
The theme of the foregoing is evolution in the management of telework. In addition, seeking the answer to the question: what is working and how to change the model of personnel management in telework? To find the answers to these questions, the author conducted a survey of managers of this type. In addition, research shows that management system has evolved significantly. And although still requirement changes, the activities are quite flexible, and adapted to the staff.
\end{abstract}

Keywords: mobile work, teleworking, disabled persons, permanent telework, alternating telework, supplementary telework

\section{Introduction}

Disabled persons exist in every local environment. The current policy in Poland requires local governments to support the disabled and help them function to a greatest possible extent like ordinary citizens, which includes the access to public utility buildings and education, etc.

Disability in this context is perceived as a limited ability of an individual to function independently. In 2001, the International Classification of Functioning, Disability and Health defined disability as a state in which an individual shows certain deviations from a normal level of functioning in three areas: biological, psychological, and social one. Consequently, it seems that disability is a conventional concept that is not always applicable in relation to social functioning.

However, despite certain limitations in the functioning, it cannot be immediately decided whether an individual is able to take up employment. Sometimes such employment does not require complicated adaptation-related actions. It may be sufficient to properly organize the position and entrust the disabled with such duties which he or she will be able to perform.

This paper presents the results of comparative studies conducted in 2007 and 2015. The studies involved the same organizations (10 business entities), which allowed the presentation of changes introduced in these organizations with regard to telework.

\section{Literature Review}

Disabled persons exist in every local environment. The current policy in Poland requires local governments to support the disabled and help them function to a greatest possible extent like ordinary citizens,

Karolina Karbownik, M.Sc., University of Technology, Czestochowa, Poland.

Correspondence concerning this article should be addressed to Karolina Karbownik, University of Technology, 14 Batorego str., PL-97-500 Radomsko, Poland. 
which includes the access to public utility buildings and education, etc.

Disability in this context is perceived as a limited ability of an individual to function independently. In 2001, the International Classification of Functioning, Disability and Health defined disability as a state in which an individual shows certain deviations from a normal level of functioning in three areas:

(a) Biological, in which the functions of an organism are lost, reduced, or distorted as a result of a damage of one or more organs being affected.

(b) Individual, which is visible in reduced activity and functioning in basic areas of one's private life.

(c) Social, which means reduced participation in social life of one's environment.

It should be noted that a disability of an individual organism in the above mentioned areas may take different forms. It depends on various factors, not only internal ones (i.e. individual factors influencing personal or environment-related characteristics), but also architectural and urban limitations, such as no access to a system of education, rehabilitation, social support, or inappropriate attitude of one's surroundings towards the disabled persons. Being a disabled person is directly related to everyday existence and participation in professional, social, and ordinary everyday life.

Majewski defines a disabled person as an individual whose affected organs or deteriorated physical condition make numerous tasks in private and professional life difficult or impossible to perform, including social roles related to one's age, gender, condition, external, social, and cultural factors (Majewski, 1995). This definition is compliant with the one specified by WHO.

Also, Charter of Rights of Disabled Persons (Karta Praw Osób Niepelnosprawnych) states that the disabled are individuals who, because of their specific physical fitness, as well as mental or intellectual condition, have permanent or temporal difficulties and limitations in their everyday life, learning process, and work, when performing social roles in accordance with legal and customary rights, or for whom such functioning is permanently or temporarily impossible.

Despite their limitations, disabled people have the right to take up employment. There are several reasons supporting it. One of them is the so-called disability mainstreaming principle, also known as an integrated approach to disabilities.

However, it is also visible that a separate legal and organizational regulation is necessary for those disabled persons whose type or level of disability makes it significantly difficult or impossible for them to function independently on the labor market, while competing with non-disabled persons.

Regardless of disabled persons' type and level of disability (and limitations imposed by it), they have the same rights to fulfill their dreams and satisfy their professional needs as other members.

Rehabilitation to professional life and employment should have the most integrating character possible. This means taking actions including initiatives, structures, programs, and instruments related to professional rehabilitation and disabled persons' employment into the structures and instruments commonly available for all society members.

(a) The right to work is one of human basic, commonly accepted personal rights that cannot be waived, as stated by the Universal Declaration of Human Rights: "Everyone has the right to work, to free choice of employment, to just and favourable conditions of work and to protection against unemployment" [article 23].

(b) International Covenant on Economic, Social and Cultural Rights sees: 
opportunity to gain his living by work which he freely chooses or accepts and will take appropriate steps to safeguard this right. The steps to be taken by a State Party to the present Covenant to achieve the full realization of this right shall include technical and vocational guidance and training programmes, policies and techniques to achieve steady economic, social and cultural development and full and productive employment under conditions safeguarding fundamental political and economic freedoms to the individual. [article 6] [originally on the basis of Dz. U. (Polish Journal of Laws) of December 29, 1977]

(c) European Social Charter includes standards directly related to the disabled persons, with disability mentioned in the specification of law, "Disabled persons have the right to professional training, rehabilitation and readaptation to social and professional life, regardless of the level or type of disability" [article 15] [Dz. U. (Polish Journal of Laws) of 1999, No. 8, item 67].

(d) The Constitution of the Republic of Poland, "Public authorities shall provide, in accordance with statute, aid to disabled persons to ensure their subsistence, adaptation to work and social communication" [article 69] [Dz. U. (Polish Journal of Laws) of 1997, no. 78, item 483].

(e) Council Resolution of 17 June 1999 on equal employment opportunities for people with disabilities (1999/C 186/02). In the resolution, the Council recognizes the need to establish equal employment opportunities for disabled persons, with "specific attention given to recruitment and retention of employees, promotion, training, life-long learning and development" (European Council Resolution of 17 June 1999 on equal employment opportunities for people with disabilities (1999/C 186/02)).

(f) Charter of Rights of Disabled Persons (Karta Praw Osób Niepełnosprawnych), "ensures the right to work in an open labor market in accordance with one's qualifications, education, and abilities" [section 6].

The European Commission defines telework as a method of organizing and performing work, in which employees perform their duties outside the company which employs them, for a part of their working time, and use information technologies and data transmission technologies (especially the Internet) to provide the employer with the results of their work.

The definition provided by the European Commission points at the organizational aspect of telework and emphasizes the fact that an employee carries out work outside the workplace.

Another definition has been provided by Telework Exchange, which presents telework as "any arrangement in which an employee regularly performs officially assigned duties at home or other work sites geographically convenient to the residence of the employee". However, this definition does not refer to the technological aspect of telework.

The researchers studying the theory of telework as a form of employment and a method of performing one's duties resulting from the employment relationship also use the following name variants of telework (Janiec, Czerniak, \& Kreft, 2006):
(a) telecommuting,
(b) remote work,
(c) flexible work,
(d) mobile work,
(e) work-at-home,
(f) e-work.

Entrepreneurs note that telework in Poland is difficult because of dated OHS regulations and other legal provisions. This situation is visible in practical operations. For instance when an employer who wants to 
improve employees' conditions of employment in order to adjust work to the employees' needs and expectations, and decides to hire a teleworker, has to cover greater costs of employment than in case of hiring a person to work at the company's site. Such higher costs result from regulations requiring the employer to provide e-worker with ergonomic equipment. What is more, the party hiring a teleworker is also responsible for controlling employees and ensuring proper OSH conditions in their workplace.

The current Labor Code of 2011 partially changes the above mentioned regulations. It requires the employer to:

(a) provide e-worker with equipment necessary to perform remote work;

(b) insure such equipment;

(c) cover any possible costs related to the equipment installation, service, exploitation, and maintenance;

(d) provide a teleworker with technical support and organize necessary training on using provided equipment.

The above provisions can be fulfilled in various ways, as they are mostly regulated in the contract between an employer and a teleworker [Dz. U. (Polish Journal of Laws), no. 181, item 1288].

Except for the above, the statute also regulates issues connected with the insurance and the principles of using provided equipment, the way of performing one's duties, and control measures.

In the case when teleworkers provide their own equipment for the performance of work, they are entitled to monetary equivalent, the value of which shall be agreed upon.

An employer also has the right to control teleworker's performance of work-related duties. However, the consent of a controlled person is necessary in this case, as specified by article $6714 \S 3$, which states that an employer shall specify the method of control, taking into account the place of performing and the character of work. This regulation is related to the fact that all control procedures must not affect e-workers' and their families' privacy. Such control cannot disturb affected persons when they use their house rooms in accordance with their intended use.

The amended Labor Code removes the employer's obligation to ensure safe and hygienic condition of a teleworker's workplace and provides proper hygiene and health facilities, especially when telework is performed at teleworker's home.

What is more, the Labor Code also states that a teleworker shall be treated differently with regard to:

(a) signing and terminating an employment contract;

(b) the conditions of employment;

(c) getting promoted and accessing trainings for the improvement of professional skills.

Mentioned different treatment is based on the comparison to other employees hired to perform the same or similar work, with its distinctiveness related to the specific conditions of telework [the act of 27 August 2007 on amending the act of Labor Code and several other acts, Dz. U. (Polish Journal of Laws), no. 181, item 1288].

The first criterion for telework type division is the scope of duties performed in the form of telework. Basing on this criterion, the following types can be determined (Greenberg \& Nilssen, 2008):

(a) permanent telework-full-time work performed remotely;

(b) alternating telework - work is partially performed remotely. On some days of a week a person works at a site, and on the remaining days, outside the workplace;

(c) supplementary telework - in this case a person works mainly at a site, but with the possibility to perform certain tasks at home, e.g. to finish some tasks that such a person was unable to complete during working hours in the company. 
Next division is based on the conditions in which e-work can be performed, including the following types (Greenberg \& Nilssen, 2008):

(a) regular work - the rules regulating remote work have been previously specified.

(b) ad hoc work - an employer agrees for telework in special circumstances that are beyond employees' control.

Telework can also be divided into types basing on the subject:

(a) full-time employment contract telework - all duties performed by the employed persons;

(b) mandate contract telework — work performed by freelancers and entrepreneurs;

The last classification of types is based on the place where telework is performed:

(a) at home,

(b) in a telecenter,

(c) during business trips (mobile or a so-called nomadic work),

(d) in any other places, e.g. during business trips, which are becoming more and more common.

Entrepreneurs note that telework in Poland is difficult because of dated OHS regulations and other legal provisions. This situation is visible in practical operations. For instance, when an employer who wants to improve employees' conditions of employment in order to adjust work to the employees' needs and expectations, and decides to hire a teleworker, has to cover greater costs of employment than in case of hiring a person to work at the company's site. Such higher costs result from regulations requiring the employer to provide e-worker with ergonomic equipment. What is more, the party hiring a teleworker is also responsible for controlling employees and ensuring proper OSH conditions in their workplace.

As a result, telework is a form of using information processing technologies (e.g. telecommunications and computer) during a business trip, when certain work is performed or transferred to the worker, instead of transferring worker to work (Kaleta, 2013).

In order to undertake any action, it is necessary to specify its area of operation. In the case of competition, the area is a so-called competition arena, where market or out-of-market competition is applicable. The former is a phenomenon between the entities located on the demand and supply sides. That is why competition includes entities which know the level of product and service demand and supply (Stankiewicz, 2005).

The second aspect of competitive operations is the subject itself. It is the basis for specifying competitors to be faced, allowing to determine their strengths and weaknesses, which facilitate actions aiming at achieving competitive advantage (Stankiewicz, 2000).

Another significant factor is the object of competition - a specification of what the competitors are competing for. This is important as competitive activities are carried out on the so-called "input" and "output" area of specific objects. What is crucial here is the resources and their reception by end customers. For competition to exist, objects have to be substitutive, and the existence of their purchasers is necessary (Begg, Fischer, \& Dornbusch, 1993).

In more generally understood competition, it is also important to specify the scope of competition, indicating the objects of analyzed operations and the possibility of their activity. In this area, the following types can be listed (Wrzosek, 2002):

(a) branch scope - answering the question whether an entity functions in one or more areas;

(b) product line scope - specifying whether competitors offer one or more key goods or services;

(c) market segment scope - characterizing the type of end customers; 
(d) vertical scope - analyzing possible links in the chain of vertical cooperation regarding a specific product;

(e) geographical scope-indicating markets of competitors' operations and providing important information on their business;

(f) competence scope - regarding individual skills necessary to prepare a specific market offer.

In modern competition it is also crucial to apply the concept of intensity indicating the tendency and ability of entities operating in the market to undertake seamless adaptation processes. It is especially important for changing market conditions, as illustrated by the following phenomena (Spyrek-Bandurska, 2015):

(a) the level of one's business dependence on consumers' behavior and markets instruments that can be applied.

(b) the ability and skills in the area of influencing customers.

That is why a turbulent environment of an organization requires that numerous innovations are implemented. Some time ago one of such innovations included online shopping, which is currently a standard option. Employees' effectiveness is also growing in importance. They want to be appreciated and have more freedom in their operations. As a result, flexible forms of employment may become a motivating factor, which can make employees more involved into their organization's operations.

\section{Analysis}

Continuous changes in today's world also force the change in the approach to telework, not only in the way the organization runs, but also in its management model.

The first important factor regarding the opinions on telework, is presented in Table 1.

Table 1

Opinions on Telework

\begin{tabular}{|c|c|c|c|c|}
\hline No. & Type of opinion in 2007 & $X=\%$ & Type of opinion in 2015 & $X=\%$ \\
\hline 1. & Telework means huge risk & 45 & $\begin{array}{l}\text { Telework is an innovation which raises } \\
\text { many doubts among the entrepreneurs }\end{array}$ & 28 \\
\hline 2. & $\begin{array}{l}\text { Telework is an innovation which can create significant } \\
\text { development opportunities for organizations in the future }\end{array}$ & 32 & $\begin{array}{l}\text { Telework can be a source of numerous } \\
\text { benefits }\end{array}$ & 26 \\
\hline 3. & $\begin{array}{l}\text { When deciding to take up telework, one should first } \\
\text { properly organize a system or e-workers management }\end{array}$ & 15 & $\begin{array}{l}\text { Telework requires changes in the way } \\
\text { organization is managed, and there is } \\
\text { some risks connected with it }\end{array}$ & 42 \\
\hline 4. & No opinion & 8 & & 4 \\
\hline
\end{tabular}

Source: Own analysis.

Pursuant to the above analysis, it can be claimed that opinions on telework vary significantly. That is why many entrepreneurs are reluctant to allow for hiring teleworkers. However, this form of employment provides the following benefits for the company:

(a) reduced costs of employment-72\% in 2015 (11\% in 2007);

(b) highly qualified new employees - $52 \%$ ( $21 \%$ in 2007 );

(c) new motivating factor included in the scope of benefits for employees- $37 \%$ ( $62 \%$ in 2007).

Another important aspect of telework is to organize a work position for this form of employment, as showed in Table 2. 
Table 2

Telework Organization

\begin{tabular}{llll}
\hline No. & The element of organization in introducing telework to the management system & $\mathrm{X}=\%$ in 2007 & $\mathrm{X}=\%$ in 2015 \\
\hline 1. & Planning works that can be performed remotely & 61 & 32 \\
2. & Specifying forms of payment settlement for employees & 20 & 45 \\
3. & Creating employee control principles & 36 & 14 \\
4. & Checking employees' skills and qualifications & 81 & 12 \\
5. & Creating the scope of factors for motivating e-workers & 31 & 49 \\
\hline
\end{tabular}

Source: Own analysis.

On the basis of the above presented data it can be claimed that currently other elements of creating teleworkers' management model are more significant than in the past. Currently, less attention is paid to the specification of which tasks can be performed, as well as to checking employees' skills and qualification prior to hiring them as teleworkers.

Table 3 below presents the elements that have changed as a result of teleworkers' development.

Table 3

Elements Changed as a Result of Teleworkers' Development

\begin{tabular}{|c|c|c|}
\hline & In 2007 & In 2015 \\
\hline $\begin{array}{l}\text { Specifying forms of payment } \\
\text { settlement for employees }\end{array}$ & $\begin{array}{l}\text { Settlement based on the work time calculated } \\
\text { by a specific program- }-81 \% \\
\text { Supervisor's telephone call- } 10 \% \\
\text { Worker's performance- }-9 \%\end{array}$ & $\begin{array}{l}\text { Worker's performance- }-74 \% \\
\text { Call/video call with a supervisor- }-11 \% \\
\text { Automatic work time calculation- }-15 \%\end{array}$ \\
\hline $\begin{array}{l}\text { Creating employee control } \\
\text { principles }\end{array}$ & $\begin{array}{l}\text { Control program }-52 \% \\
\text { Talk with a supervisor- }-37 \% \\
\text { Reporting }-21 \%\end{array}$ & $\begin{array}{l}\text { Autocontrol- } 38 \% \\
\text { Reporting- } 31 \% \\
\text { Talk with a supervisor- }-27 \% \\
\text { Program-4\% } \\
\text { Trial period- } 61 \%\end{array}$ \\
\hline $\begin{array}{l}\text { Checking employees' skills and } \\
\text { qualifications }\end{array}$ & $\begin{array}{l}\text { Trial period }-52 \% \\
\text { Employment in a traditional form first }-48 \%\end{array}$ & $\begin{array}{l}\text { Tests }-18 \% \\
\text { Employment in a traditional form } \\
\text { first }-21 \%\end{array}$ \\
\hline $\begin{array}{l}\text { Creating the scope of factors } \\
\text { motivating e-workers }\end{array}$ & Financial bonuses- $-100 \%$ & $\begin{array}{l}\text { Financial bonuses }-38 \% \\
\text { Chance for promotion- }-21 \% \\
\text { Personal development opportunities- }-18 \% \\
\text { Awards }-12 \%\end{array}$ \\
\hline
\end{tabular}

Source: Own analysis.

The analysis of the above Table shows that certain aspects that used to be quite problematic, are now dominating. What is mostly visible is a trend to democratize work, enabling teleworkers to demonstrate their skills, and leaving remote workers a lot of freedom in their operations.

Despite numerous benefits of telework and its continuous development, many entrepreneurs are still concerned about the results of accepting this form of employment. Even though the changes introduced in this form of employment show that telework is more commonly used, there are numerous concerns, and the basic ones include the following:

(a) The employers are concerned that teleworkers will not cope with their duties- $55 \%$ (increase by $21 \%$ as compared to 2007); 
(b) There is a concern that e-workers cannot be fully controlled-28\% (decrease by $39 \%$ as compared to 2007);

(c) No proper personnel that allows for telework and controls e-workers-18\% (reported decrease by $25 \%$ as compared to 2007);

(d) Lack of proper knowledge-31\% (decrease by nearly $34 \%$ as compared to 2007 ).

Thus, as presented, it may be claimed that this form of employment can satisfy current employees' needs, but it is still a source of numerous concerns. As a result, many organizations could use the benefits of telework, but they decide not to do so and, consequently, limit their own use of innovations.

\section{Conclusions}

Many changes in the 20th century brought about groundbreaking developments, also in the functioning and management of organizations. The greatest revolution of this period was computerization and the introduction of the Internet. As a result, numerous duties of individual workers started to be performed by computers, and there was no need for a physical presence of these workers at a site (author's note).

The possibility to quickly exchange information, regardless of the distance, allowed for the introduction of telework - a new way of performing work-related duties. This, in turn, required the implementation of new solutions, e.g. in the area of personnel supervision and management, as it is impossible to personally observe teleworkers and the way they perform their obligations. What is more, remote work imposes certain limitations on the traditional motivational system. For instance, it is difficult to verbally praise such workers in front of the team, as all members are in different geographical locations.

The analysis of collected primary sources has presented that many employers are concerned about introducing this form of employment in their companies, and they choose not to use this possibility. However, conducted research shows that telework is mostly a source of benefits for the enterprise, as telework is a possibility to hire and keep valuable, highly qualified personnel, including persons in difficult personal situations, whose everyday presence at the company's site would be impossible, in which case it is possible to receive co-financing for the employment of such e-worker and reduce other employment costs. Still, there are also certain risks related to telework, such as the risk of revealing company's secret information to incompetent persons. What is more, it is difficult to control teleworkers and there is a possibility that an employee will not be a reliable, honest, and loyal teleworker. Still, remote work satisfies many current needs of both employees and employers, and it seems that it will be used more and more commonly.

\section{References}

Begg, D., Fischer, S., \& Dornbusch, S. (1993). Państwowe Wydawnictwo Ekonomiczne. Ekonomia, 57-58.

Greenberg, A., \& Nilssen, A. (2008). Telepraca-odpowiedź na wyzwania związane z rozproszonym biznesem XXI wiek. Wainhouse Research, 178-179.

Janiec, M., Czerniak, T., \& Kreft, W. (2006). Prowadzenie działalności biznesowej z wykorzystaniem telepracy. Polska Agencja Rozwoju Przedsiębiorczości, Warszawa, 181-183.

Kaleta, A. (2013). Ryzyko wyboru strategicznego i metody jego ograniczenia. in E. Urbanowska-Sojkin, and M. Brzozowski, Ryzyko w zarzadzaniu strategicznym. Natura i uwarunkowania, 145-147. Wydawnictwo Uniwersytetu Ekonomicznego, Poznań.

Labor Code of 27 August 2007. (2007). On the rights and obligations of teleworkers and employers employing in the form of telework (the act of 27 August 2007 on amending the act of Labor Code and several other acts, Dz. U.). Polish Journal of Laws (no. 181, item 1288). 
Majewski, T. (1995). Rehabilitacja zawodowa osób niepełnosprawnych. Centrum Badawczo-Rozwojowe Rehabilitacji Osób Niepetnosprawnych, 121. Warszawa.

Spyrek-Bandurska, G. (2015). Telepraca jako nietypowa forma zatrudnienia w Polsce. Aspekty prawne $i$ społeczne. Warszawa: Oficyna Wydawnicza Aspra-JR.

Stankiewicz, M. (2000). Istota i sposoby oceny konkurencyjności przedsiębiorstwa. Gospodarka Narodowa, (7-8/2000), 23-24.

Stankiewicz, M. (2005). Konkurencyjność przedsiębiorstwa. Budowanie konkurencyjności przedsiębiorstwa w warunkach globalizacji. Warszawa: Towarzystwo Naukowe Organizacji i Kierownictwa "Dom Organizatora".

Wrzosek, W. (2002). Funkcjonowanie rynku. Warszawa: PWE. 